\title{
Is the Alternative Exchange achieving its objectives? A capital structure perspective
}

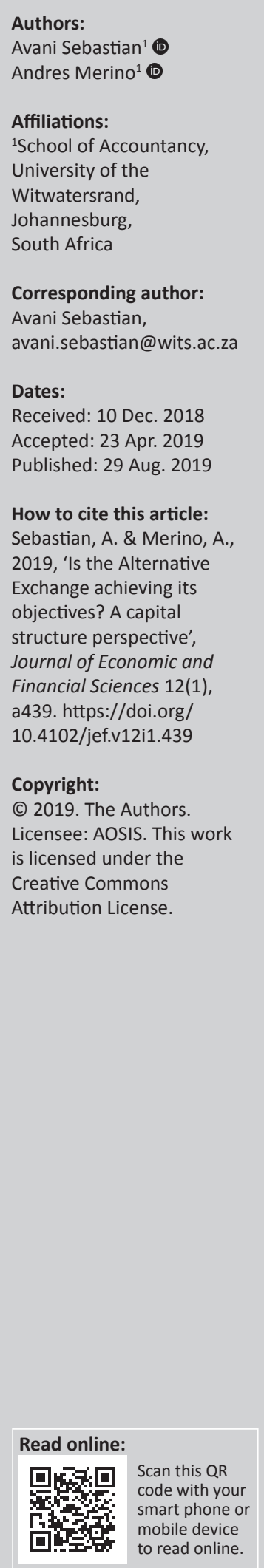

Orientation: Despite their significant contribution to the South African economy, the majority of small and medium enterprises (SMEs) fail because of lack of access to appropriate types of capital. The Alternative Exchange (AltX) was established to address the lack of access to equity finance for SMEs.

Research purpose: This study aims to determine whether the AltX has adequately enabled access to equity finance for the firms listed thereon.

Motivation for the study: This study was motivated by the apparent lack of SME access to appropriate forms of finance. By evaluating the effectiveness of the AltX, the study seeks to investigate whether further measures are required to enable access to equity finance for SMEs.

Research design, approach and method: A quantitative methodology was employed and panel regression models were used to compare the levels of equity and debt of firms listed on the AltX to those listed on the Johannesburg Securities Exchange's (JSE) main board. In this manner, the study aims to determine whether AltX firms enjoy the same level of access to capital markets as their counterparts on the JSE.

Main findings: The findings indicate that firms listed on the AltX have significantly higher levels of debt than those listed on the JSE's main board. This debt tends to be the more accessible yet risky short-term debt.

Practical/managerial implications: The findings infer that despite the establishment of the AltX, SMEs still face considerable constraints to accessing equity finance and, as such, may be compelled to consider other means of raising finance.

Contribution/value-add: This study contributes to the research on SMEs in South Africa and suggests that further interventions are required to enable their access to appropriate forms of finance.

Keywords: capital structure; AltX; JSE; SME; information asymmetry; equity; pecking order; liquidity risk; panel data regression.

\section{Introduction}

\section{Orientation}

Capital structure theories are often linked to firm value making the topic relevant in the context of economic growth (Jensen 1986; Miller 1977; Modigliani \& Miller 1958, 1963; Myers \& Majluf 1984). In the developing South African economy, small and medium enterprises (SMEs) are firms that are essential contributors to employment and gross domestic product (GDP) and provide competition to larger firms (Olawale \& Garwe 2010). Estimations indicate a probable contribution to GDP of more than $50 \%$ and a contribution to employment of more than $60 \%$ in South Africa (Abor \& Quartey 2010; Falkena et al. 2007). Small and medium enterprises are viewed as a means to achieving a dynamic and flourishing private sector as well as to ensure development that is more equitable (Beneke 2016). The role of finance is a critical element for the development of SMEs as a large portion of the SME sector does not have access to adequate and appropriate forms of credit and equity (Cook \& Nixson 2000). An analysis of the capital structure of SMEs may provide valuable guidance on how to encourage their growth.

The Alternative Exchange (AltX) is the secondary exchange to the Johannesburg Securities Exchange (JSE). It was launched in 2003 as a market for SMEs that have high growth rates (Correia \& Holman 2008). The primary objective of the AltX is to be a growth catalyst to South African SMEs by enabling access to finance (JSE 2013). 
Stock exchanges play a key role in enabling access to finance. Besides allowing companies to enjoy access to capital through equity issues, they encourage specialisation as well as acquisition and dissemination of information. Furthermore, well-developed stock exchanges may mitigate the principalagent problem by aligning the interests of managers and owners so that managers strive to maximise firm value. Access to capital markets without having to comply with relatively onerous main board listing requirements improves the allocation of capital, which is an important channel of economic growth (Arestis, Demetriades \& Luintel 2001; Yartey \& Adjasi 2007). In an African context, Yartey and Adjasi (2007) cite the development of stock exchanges as central to the domestic financial liberalisation process.

The success of SMEs is one of the main areas of concern of many policymakers as they attempt to accelerate the growth of developing economies (Abor \& Quartey 2010). Small and medium enterprises are easier to establish than their larger counterparts and are usually more adaptable to changing market conditions. They, therefore, generate returns more rapidly. These firms are less likely to use advanced technology and are more likely to rely on labour, contributing to the creation of employment in the economy (Beneke 2016; Falkena et al. 2007). Moreover, they contribute to a more even distribution of economic activity as they are more likely to succeed in smaller, underserviced urban centres (Abor \& Quartey 2010).

Governments provide incentives to these firms as they are seen as making a significant contribution to the alleviation of poverty in the economies in which they operate (Cook \& Nixson 2000). In South Africa, R3.9 billion was allocated to supporting the growth of SMEs in 2017 (Gordhan 2017). Furthermore, South African SMEs have the potential to be an engine for black economic empowerment (Falkena et al. 2007).

In South Africa, capital structure research has mainly focussed on large listed companies trading on the main board of the JSE (Correia \& Cramer 2008; Gwatidzo \& Ojah 2009; Lemma \& Negash 2011; Letsoenya \& Negash 2013). A study of the capital structure of smaller firms may, therefore, be a relevant yet largely unexplored area of research in South Africa. Correia and Cramer (2008) found that large listed companies in South Africa have low levels of debt in relation to what is predicted by trade-off theory. The trade-off theory views the firm as having an optimal capital structure that involves the trade-off between the benefits of debt and its costs to arrive at a value-maximising capital structure (Kraus \& Litzenberger 1973). The low debt levels in South African companies are despite the country's relatively sophisticated financial markets (De Wet \& Gossel 2016; Gwatidzo \& Ojah 2009). Possible reasons for these low debt levels relate to high profitability levels in the domestic economy but limited growth prospects for expansion as well as a reluctance or inability to expand into international markets (Correia \& Cramer 2008). These findings strengthen the case for a similar study into SMEs in South Africa.
Despite the crucial role of SMEs in the South African economy, their failure rate is estimated at between 70\% and 80\% (Cant \& Ligthelm 2002). In a study on South African SMEs, Olawale and Garwe (2010) found that the main inhibitors of growth were related to capital structure as access to finance and insufficient owner's equity contribution were among the top three obstacles cited by respondents. Insufficient access to dynamic capital markets for SMEs in South Africa is one of the main reasons for business discontinuance (Abor \& Quartey 2010; Falkena et al. 2007; SEDA 2016).

\section{Research purpose and objectives}

The purpose of this study is to determine whether the AltX has adequately enabled access to equity finance for companies listed thereon. To this end, the research questions addressed by this study are as follows:

- Is there a significant difference between the capital structures of firms listed on the AltX and those listed on the JSE's main board? This will be addressed by the first hypothesis as detailed in the 'Literature review' section.

- If so, what are the factors driving the difference? This will be addressed by Hypotheses 2-6 as detailed in the 'Literature review' section.

The empirical analysis in this study focussed on non-financial firms listed on the JSE and AltX over the 5-year period (2011-2015). The data were analysed using descriptive statistics and panel data regression models. The first regression model, Equation 1, was used to determine whether a significant difference in capital structures existed between firms listed on the AltX and those listed on the main board of the JSE. The second model, Equation 2, was used to analyse the differences in capital structure between the indices.

This study is structured as follows. 'Literature review' section provides a review of the literature where the capital structure framework is detailed and related to SMEs. 'Research design' section explains the research methodology and details the models and panel data regression techniques. The outcomes of the models are discussed in detail in the 'Results' section. Finally, the study concludes in the last section with a comparison to prior empirical findings, practical implications and recommendations for future research.

\section{Literature review}

Financial theories such as those in Modigliani and Miller (1958), trade-off, pecking order, agency and information asymmetries are equally relevant to the financing behaviour of small and large firms (Ang 1992). The influential work on capital structure and firm value by Modigliani and Miller (1958) forms the basis of the capital structure theoretical framework. The underlying premise of the Modigliani and Miller (1958) proposition is that in perfect securities markets, the capital structure decisions by firms belonging to the same risk class do not alter the opportunity set available to investors. Hence, any discrepancies in total market values of identical firms in the same risk class arising from differences in 
financing mix will be removed through arbitrage operations by investors. Once the perfect market assumptions are relaxed, the effect of capital structure on firm value becomes apparent.

Several capital structure theories have since provided insights into the factors affecting firms' financing decisions. The trade-off theory views the firm as having an optimal capital structure, which involves the trade-off between the benefits of debt and its costs to arrive at a value-maximising capital structure (Kraus \& Litzenberger 1973). The free cash flow theory from Jensen (1986) suggests that the use of debt imposes discipline on management to invest in positive net present value projects only. Pecking order theory suggests that firms go through a specific hierarchy of financing options with the intention of exhausting internal sources of funding before raising capital from external sources (Myers \& Majluf 1984). Inherent in the pecking order theory is the assumption of information asymmetries between the firm's managers and its providers of capital. The theory recognises the existence of transaction costs that compel firms to follow a pecking order. Research on firms listed on the JSE has indicated support for the pecking order theory (Gwatidzo \& Ojah 2009; Lemma \& Negash 2011; Ramjee \& Gwatidzo 2012). Correia and Cramer (2008) found that while a relatively large proportion of main board listed firms use a strict debt equity ratio, these ratios were lower than what is predicted by trade-off theory.

The rest of this section explains the theoretical and empirical reasons for including the chosen variables in the study by presenting findings from other empirical works of research. It explains various features of SME capital structure in relation to the capital structure theoretical framework. The results of prior empirical analysis appear to have yielded evidence of both positive and negative relationships between the chosen explanatory variables, control variables and leverage. This study presents perspectives from prior studies where differing findings were reached.

\section{Leverage}

In this study, leverage is used as the dependent variable to provide an indication of capital structure. Capital structure theories have different implications depending on how leverage is defined (Harris \& Raviv 1991; Lemma \& Negash 2011; Rajan \& Zingales 1995). As results from previous studies suggest that the debt duration varies as firm size changes, separate measures are required for short-term, long-term and total debt, respectively. This study employs five measures of leverage which include both short-term and long-term measures. These are articulated in detail in the 'Research design' section. Short-term debt is measured using current liabilities, while long-term debt is measured using noncurrent liabilities. Total liabilities are used as the measurement proxy for total debt.

Consistent with Rajan and Zingales (1995), 'net assets' used in the first measure of leverage is calculated as the total assets less 'trade and other payables'. Therefore, an increase in the amount of trade payables will result in a reduction in this measure of leverage. This is useful in analysis as the level of accounts payable may be influenced by industry considerations and this measure of leverage isolates these effects (Rajan \& Zingales 1995).

\section{The Alternative Exchange}

As suggested in Sebastian and Kransdorff (2017), a possible solution to the apparent lack of access to finance that SMEs face is the establishment of an exchange exclusively for these firms. Gwatidzo and Ojah (2009) suggest that enhancing institutional infrastructures would enhance capital structure decisions of firms in Africa. The AltX was established to provide SMEs with access to long-term equity finance, which was previously reserved for firms listed on the main board (JSE 2013). A possible impediment to smaller companies listing on the JSE's main board is the onerous listing requirements. According to Van Heerden (2015), the listing requirements of the $\mathrm{Alt} X$ are, therefore, not as onerous as those for the JSE. A comparison of the principal listing requirements of the AltX and the JSE's main board is synthesised in Table 1 .

In light of the relaxed corporate governance requirements for AltX listings, Scholtz and Smit (2015) acknowledge that these companies would not typically invest in expensive mechanisms to improve the independence of their boards as they pursue growth opportunities. In this manner, the AltX supports the growth efforts required for the firms that list thereon.

Furthermore, Van Heerden (2015) suggests that the AltX has been successful in its goal of offering an opportunity for SMEs to raise capital and be a springboard to the main board of the JSE. This conclusion is largely predicated on the findings that the JSE experienced more de-listings than the AltX and the latter experienced more listings than de-listings for the period under analysis.

TABLE 1: A comparison of listing criteria of the Alternative Exchange and the Johannesburg Securities Exchange's main board.

\begin{tabular}{ll}
\hline AltX & Main board \\
\hline Share capital of at least R2 000000 & $\begin{array}{l}\text { A subscribed capital of at } \\
\text { least R50 million and not } \\
\text { less than } 25 \text { million } \\
\text { equity shares in issue. }\end{array}$ \\
$\begin{array}{ll}\text { A profit forecast for the remainder of the financial year } \\
\text { of listing and one full financial year thereafter. }\end{array}$ & $\begin{array}{l}\text { A satisfactory audited } \\
\text { profit history for the } \\
\text { preceding three financial } \\
\text { years. }\end{array}$ \\
$\begin{array}{ll}\text { The public must hold a minimum of 10\% of each class } \\
\text { of equity securities. }\end{array}$ & $\begin{array}{l}\text { Twenty per cent of each } \\
\text { class of equity securities } \\
\text { should be held by the } \\
\text { public. }\end{array}$ \\
$\begin{array}{l}\text { The appointment of a designated adviser. } \\
\text { The directors must have completed the AltX Directors }\end{array}$ \\
$\begin{array}{l}\text { Induction Programme or must make arrangements to } \\
\text { the satisfaction of the JSE to complete it. }\end{array}$ \\
$\begin{array}{l}\text { The auditors or attorneys must hold in trust 50\% of the } \\
\text { shareholding of each director and the designated adviser. }\end{array}$ \\
\hline $\begin{array}{l}\text { Source: JSE, 2016, Guidelines to listing on the JSE, Lexis Nexis Butterworths Publishers, } \\
\text { viewed 16 March 2019, from https://www.jse.co.za/content/JSESpecificationsltems/ }\end{array}$ \\
$\begin{array}{l}\text { Guidelines\%20to\%20Listing\%20on\%20the\%20JSE.pdf } \\
\text { AltX, Alternative Exchange; JSE, Johannesburg Securities Exchange. }\end{array}$
\end{tabular}


Research on AltX equivalents in various countries highlights the challenges faced in promoting growth of SMEs. London's privately regulated Alternative Investment Market (AIM) has been effective in providing finance to small, high-growth companies (Mendoza 2008) although these firms still experience a high failure rate and are unlikely to move to larger exchanges (Gerakos, Lang \& Maffett 2013). In 2005, 40 companies moved directly from the London Stock Exchange to the AIM, while only two companies moved from AIM to the main board.

From an emerging market perspective, the Over the Counter Exchange of India (OTCEI) failed in its objective to provide access to finance to SMEs in India (Banerjee 2006). Among the reasons for the OTCEI's failure according to Banerjee (2006) were onerous listing requirements and high levels of information asymmetry. The findings of the Commission of Enquiry on Small Firms, as cited by Holmes and Kent (1991), indicated that small firms suffered from a 'finance gap' - the result of limited access to capital markets. Smaller firms therefore had to resort to more expensive financing which hindered their development (Sebastian \& Kransdorff 2017).

The establishment of the AltX may have alleviated some of these pressures for SMEs in South Africa by allowing access to the same capital markets as firms listed on the main board. To determine whether AltX companies have the same level of access to capital markets as firms listed on the main board, this study hypothesises as follows:

Hypothesis 1: There is a significant difference in the capital structure of firms on the AltX and JSE.

\section{Term structure of debt}

Prior literature indicates that the term structure of debt varies between larger and smaller firms with smaller firms relying more on short-term financing. The apparent difficulty experienced by small firms in raising long-term debt may be predicated on theories of information asymmetry (Titman \& Wessels 1988). Asymmetric information between owners and outsider capital suppliers could cause a large gap in the cost of funds perceived by the owners and by suppliers of capital. As the providers of short-term capital interact with the firm more frequently, they may have a more intimate knowledge of the firm than the providers of long-term debt (Ang 1992; Damodaran 2010).

Research on African firms provides evidence that where these firms need debt to finance their production activities, they choose mostly short-term debt (Gwatidzo \& Ojah 2009). Titman and Wessels (1988) found short-term debt ratios to be negatively correlated to firm size - a possible result of relatively high transaction costs of long-term debt for small firms. They posit that small firms pay more than large firms to issue long-term debt and therefore prefer to borrow short term because of the lower fixed costs associated with this type of debt. If debt is required, SMEs will choose short-term debt as it is unlikely to have covenants that impose limitations on managers' control - evidence of the pecking order theory. This study therefore tests the following hypothesis:

Hypothesis 2: The term structure of debt depends significantly on firm size.

\section{Taxes}

In the presence of corporate taxes, the capital structure irrelevance theory of Modigliani and Miller (1958) no longer holds and taxes do affect financing decisions. By virtue of the tax deductibility of interest, debt is viewed as a cheaper form of capital, which increases the value of the firm. Unlike interest payments, the payment of dividends to equity holders is not tax-deductible. Graham (2000) makes reference to the unsolved 'riddle' of why many firms appear conservative in their use of debt despite the sizable benefit available from the tax deductibility of interest. According to Lee and Barker (1977), the optimal leverage is at the point where the present value of the tax shield is equal to the present value of the cost of financial distress.

There are varied findings on the effect of tax on leverage in South African firms. The analysis performed by Negash (2002) yielded a negative association between tax rate variables and the extent of leverage, while that of Gwatidzo and Ojah (2009) found that the tax variable was insignificant. Moyo, Wolmarans and Brummer (2013) posit that profitable firms face increased tax payable, and they reduce this through the use of debt interest tax shields.

It is therefore uncertain whether tax rates will be positively or negatively correlated with leverage. This study therefore tests the following hypothesis:

Hypothesis 3: A significant relationship exists between tax and leverage.

\section{Size}

The existence of bankruptcy costs associated with debt leads to the trade-off theory between tax and bankruptcy costs (Kraus \& Litzenberger 1973; Modigliani \& Miller 1963). There are benefits and costs associated with debt. The benefits stem from the interest being tax-deductible, while higher debt levels increase the probability of bankruptcy and financial distress. This is why, in reality, there is a moderate, cautious approach to borrowing as opposed to a capital structure composed entirely of debt (Gwatidzo \& Ojah 2009). This theory is particularly relevant for SMEs as they have a greater chance of landing in financial distress than their larger counterparts (Ang 1992; Bhaduri 2002).

Prior literature links the cost of financial distress to the size of the firm. Prasad, Green and Murinde (2001) chose size as a proxy for the inverse likelihood of default. In their study of JSE-listed firms, Holman, Van Breda and Correia (2011) noted that firm size is related to the probability of default. It follows then that the larger the firm, the lower the probability of default. The economies of scale related to bankruptcy costs are highlighted in a study on developing 
economies by Prasad et al. (2001). In the study, larger firms are shown to face lower unit costs of bankruptcy than do smaller firms. Similarly, the findings in Ang, Chua and McConnell (1982) suggest that bankruptcy costs constitute a larger proportion of a firm's value as its size decreases.

Under the assumption that liquidation is costly, smaller firms should be more averse to debt. Rajan and Zingales (1995) postulate that larger firms tend to be more diversified and fail less often. Similarly, Prasad et al. (2001) suggest that higher leverage in firms, which manufacture products across a number of industries, are diversified and less prone to collapse. In a study that included South African firms, Gwatidzo and Ojah (2009) found that the relationship between size and leverage was positive and significant. Moyo et al. (2013) found a significant negative correlation between financial distress and the firms' leverage in the manufacturing, mining and retail industries in South Africa. This study tests the following hypothesis:

Hypothesis 4: There is a significant relationship between firm size and leverage.

\section{Asset structure}

Theories on information asymmetry suggest that firms may prefer to raise secured debt (Myers \& Majluf 1984; Sardo \& Serrasqueiro 2017). Akerlof (1970) explains that the availability of credible information is critical to the functioning of vital markets in an economy. Firms that cannot credibly signal their quality to providers of finance can incur an increased premium as a result of lack of information. The practice of offering property with known values as collateral may reduce these costs. Therefore, firms with assets that can be used as collateral may take advantage of their increased opportunities to access debt. Gwatidzo and Ojah (2009) note that the prevalence of information asymmetry is high in the African environment. Similarly, Sardo and Serrasqueiro (2017) find high costs of information asymmetry in the Portuguese capital markets. In contrast, Moyo et al. (2013) find asset tangibility to be negatively related to leverage when considering South African firms in the manufacturing, mining and retail industries only.

From the perspective of the providers of debt finance, Long and Malitz (1985) found that lenders are likely to prefer tangible assets with an active second-hand market as collateral as they will be easier to liquidate. Bevan and Danbolt (2002) found that leverage is significantly positively correlated with tangibility. Research on South African firms has shown that firms with tangible assets find it easier to access debt finance (Gwatidzo \& Ojah 2009; Lemma \& Negash 2011). Therefore, this study hypothesises as follows:

Hypothesis 5: A significant relationship between asset structure and leverage exists.

\section{Profitability}

According to the pecking order theory, firms prefer internal to external sources of financing (Myers \& Majluf 1984).
The theory suggests that firms go through a specific hierarchy of financing options when it comes to raising capital - their first choice is retained earnings, second debt and, as a last resort, the issue of new equity. Firms therefore prefer internal sources of funding before exhausting their debt capacity. A possible explanation is that firms draw on internal sources of finance that will not dilute their control; either as a result of restrictive debt covenants or new shareholders. Therefore, firms with high levels of cash resources will forgo additional debt. Accordingly, Myers and Majluf (1984) predict a negative relationship between profitability and debt as highly profitable companies will tend to finance investment with internal funds rather than debt.

Several studies agree that leverage decreases with profitability (Bevan \& Danbolt 2002; Booth et al. 2001; Lemma \& Negash 2011; Rajan \& Zingales 1995). Furthermore, the negative influence of profitability on leverage became stronger as firm size increases (Rajan \& Zingales 1995). Holmes and Kent (1991) suggest that small firms have a preference for those financing options which minimise intrusion into their businesses.

Titman and Wessels (1988) assert that the past profitability of the firm and hence its retained earnings should be an important determinant of its capital structure. Studies on developing economies show that the more profitable the firm, the lower the debt ratio (Booth et al. 2001; Perera 2015; Prasad et al. 2001). These findings are supported by some studies on South African firms (Gwatidzo \& Ojah 2009; Lemma \& Negash 2011). In contrast, Moyo et al. (2013) found a significant positive relationship between leverage and profitability of firms in the manufacturing, mining and retail industries. Therefore, the final hypothesis of this study is:

Hypothesis 6: There is a significant relationship between profitability and leverage.

\section{Research design}

The purpose of this study is to determine whether the AltX has sufficiently enabled access to equity finance for the firms listed thereon. The JSE is used as a benchmark and the capital structures of firms listed on the AltX are compared to those listed on the JSE's main board to test whether a significant difference exists and, if so, what are the factors driving the difference.

\section{Research approach}

This study follows a quantitative method of research. The intention of quantitative research is to establish, confirm or validate relationships (Leedy \& Ormrod 2012).

The sample for the study is based on panel data of the 5-year period from 2011 to 2015. It comprises all companies that were listed on the AltX and the JSE at any point during the period under analysis. Therefore, firms that may have subsequently delisted from either exchange are included in 
the analysis. This creates an unbalanced panel but, in doing so, survivorship bias is eliminated (Brown et al. 1992). A similar approach was employed in prior studies where data were gathered from databases, which included companies that had delisted from their respective local market index (Bevan \& Danbolt 2004; Rajan \& Zingales 1995).

Firms were selected from the JSE and AltX if they had financial data available for any periods in the 5 years under analysis. Thereafter, all companies in the financial services sector were excluded from the analysis as these firms are subject to special regulations that may influence their capital structure. Before any statistical analysis, 234 firms were identified, of which 189 were listed on the JSE and 45 were on the AltX.

Following precedent (Chipeta, Wolmarans \& Vermaak 2012; Chipeta et al. 2013; Lemma \& Negash 2011; Letsoenya \& Negash 2013), firms within the financial services sector have been excluded from the analysis because their borrowing capacity and capital adequacy requirements are subject to separate regulation. This regulation therefore impacts their capital structure.

The data for this study were drawn from INET BFA database (formerly known as the McGregor BFA database). All data were managed using Microsoft Excel 2010 and statistical analysis was performed in the software package, $\mathrm{R}$ (Croissant \& Millo 2008).

Measurement proxies have been used for the estimation of explanatory variables as outlined in the 'Literature review' section of this study. The findings and interpretations thereof may vary if alternative approximations are used.

This study uses book values of leverage rather than market values. Bowman (1980) found that accounting measures of debt were not significantly different from their market values. Titman and Wessels (1988) conclude that an accounting measure may be a very good surrogate for market value of debt. It is therefore unlikely that the results of this study will be substantially different if market values had been used.

TABLE 2: Distribution of sampled firms by sector classification (Johannesburg Securities Exchange and Alternative Exchange firms).

\begin{tabular}{lccccc}
\hline Sector & \multicolumn{2}{c}{ Number of firms } & & \multicolumn{2}{c}{ Percentage } \\
\cline { 2 - 3 } \cline { 6 - 7 } & JSE & AltX & & JSE & AltX \\
\hline Basic materials & 47 & 8 & & 24.87 & 17.78 \\
Consumer goods & 17 & 4 & & 8.99 & 8.89 \\
Consumer services & 39 & 3 & & 20.63 & 6.67 \\
Health care & 6 & 2 & & 3.17 & 4.44 \\
Industrials & 63 & 18 & & 33.33 & 40.00 \\
Oil and gas & 3 & 0 & & 1.59 & 0.00 \\
Utilities & 0 & 1 & & 0.00 & 2.22 \\
Technology & 9 & 8 & & 4.76 & 17.78 \\
Telecommunications & 5 & 1 & & 2.65 & 2.22 \\
\hline Total & $\mathbf{1 8 9}$ & $\mathbf{4 5}$ & & $\mathbf{1 0 0 . 0 0}$ & $\mathbf{1 0 0 . 0 0}$ \\
\hline
\end{tabular}

Source: INET database and authors' computations

AltX, Alternative Exchange; JSE, Johannesburg Securities Exchange.

\section{Statistical analysis}

As indicated in the 'Literature review' section, leverage is the dependent variable in the model used in this study. The effect on leverage of the index listing (i.e. either AltX or JSE), firm size, asset structure, taxation and profitability were analysed using regression models.

As in Sebastian and Kransdorff (2017), the linear regression models in this study were run separately using each of the five measures of leverage (Lev_1 to Lev_5) as detailed in Table 3 in this section. Results from previous studies suggest that the debt duration varies as firm size changes. Therefore, separate measures are used for short-term, long-term and total debt, respectively. Short-term debt is measured using current liabilities in Lev_4 (Current liabilities/Total assets), while long-term debt is measured using non-current liabilities in Lev_5 (Non-current liabilities/Total liabilities). Total liabilities are used as the measurement proxy for total debt in Lev_1 (Total liabilities/Net assets), Lev_2 (Total liabilities/ Total assets) and Lev_3 (Total liabilities/Equity).

The panel data available for this study lend itself to panel data regression analysis (Baltagi 2008; De Jager 2008). For the analysis, the fixed effects model and the random effects model were estimated. The choice between the models depends on the assumptions made about the error term. The random effects model assumes that the individual specific error component (or the individual heterogeneity) is random, while the fixed effects model ignores the unit-specific residual (Gwatidzo \& Ojah 2009). To assess the suitability of each of the models, the Hausman test was conducted. The results of this test are detailed in the 'Results' section of this study.

As indicated in the 'Literature review' section, leverage is the dependent variable in this study. The linear regression models in this study were run separately using each of the five measures of leverage (Lev_1 to Lev_5) as detailed in Table 3 in this section.

Results from previous studies suggest that the debt duration varies as firm size changes. Therefore, separate measures are used for short-term, long-term and total debt, respectively.

TABLE 3: Measurement of variables.

\begin{tabular}{|c|c|c|}
\hline Variable & Measurement & Precedent \\
\hline Leverage & $\begin{array}{l}\text { Total liabilities/net assets (Lev_1), } \\
\text { total liabilities/total assets (Lev_2), } \\
\text { total liabilities/equity (Lev_3), } \\
\text { current liabilities/total assets (Lev_4), } \\
\text { non-current liabilities/total liabilities } \\
\text { (Lev_5) }\end{array}$ & $\begin{array}{l}\text { Letsoenya and Negash } \\
\text { (2013), Rajan and Zingales } \\
\text { (1995), Lemma and } \\
\text { Negash (2011) }\end{array}$ \\
\hline Size (SIZE) & Natural logarithm of total turnover & $\begin{array}{l}\text { Rajan and Zingales (1995), } \\
\text { Bevan and Danbolt (2002), } \\
\text { Titman and Wessels (1988) } \\
\text { Lemma and Negash (2011) }\end{array}$ \\
\hline Tax & $\begin{array}{l}\text { Tax paid (per the cash flow } \\
\text { statement)/profit before interest and } \\
\text { tax }\end{array}$ & Lemma and Negash (2011) \\
\hline $\begin{array}{l}\text { Asset structure } \\
\text { (ASSETSTRUCT) }\end{array}$ & $\begin{array}{l}\text { Tangible/total assets } \\
\text { (where tangible plus intangible } \\
\text { assets equal total assets) }\end{array}$ & $\begin{array}{l}\text { Sogorb-Mira (2005), Bevan } \\
\text { and Danbolt (2002), } \\
\text { Lemma and Negash (2011) }\end{array}$ \\
\hline $\begin{array}{l}\text { Profitability } \\
\text { (PROFIT) }\end{array}$ & $\begin{array}{l}\text { Earnings before interest and taxes/ } \\
\text { total assets }\end{array}$ & $\begin{array}{l}\text { Sogorb-Mira (2005), Bevan } \\
\text { and Danbolt (2002), } \\
\text { Lemma and Negash (2011) }\end{array}$ \\
\hline
\end{tabular}


Short-term debt is measured using current liabilities in Lev_4 (Current liabilities/Total assets), while long-term debt is measured using non-current liabilities in Lev_5 (Non-current liabilities/Total liabilities). Total liabilities are used as the measurement proxy for total debt in Lev_1 (Total liabilities/ Net assets), Lev_2 (Total liabilities/Total assets) and Lev_3 (Total liabilities/Equity).

$\operatorname{LEVERAGE}(k)_{i t}=\alpha+\beta 1 \times(\ln (\operatorname{SIZE}))_{i t}+\beta 2 \times(\mathrm{TAX})_{i t}+$ $\beta 3 \times(\text { ASSETSTRUCT })_{i t}+\beta 4 \times(\text { PROFIT })_{i t}+$

$\beta 5 \times\left(\mathrm{CD}_{-} \text {Listing }\right)_{i t}+\varepsilon_{i t}$

[Eqn 1]

where:

$i$ denotes the cross sections and $t$ denotes the time period with $i=1 \ldots 234$ and $t=1, \ldots, 5$. The yearly observations are from 2011 to 2015.

LEVERAGE $(k)$ represents different leverage measures (total liabilities/net assets, total liabilities/total assets, total liabilities/capital, current liabilities/total assets, non-current liabilities/total liabilities) with $k=1,2,3,4$ and 5. This equation is run five times - once for each measure of leverage.

CD_Listing is a coded variable indicating whether the firm is listed on the AltX (-1) or the JSE (1) $\varepsilon_{i t}$ is the normal error term.

$\alpha$ is the constant.

The first equation tests whether there is a significant difference in the capital structure of AltX-listed firms and JSE-listed firms, holding all other major known determinants of capital structure constant. It aims to isolate the effect that the index has on the capital structure of a firm. Therefore, the following are the control variables:

- $\quad$ Size (SIZE)

- Taxes (TAX)

- Asset Structure (ASSETSTRUCT)

- Profitability (PROFIT).

The second equation determines the differences in factors affecting capital structure of AltX- and JSE-listed firms. Therefore, the regression analysis will be performed with AltX firms only and then with JSE firms only.

$\operatorname{LEVERAGE}(k)_{i t}=\alpha+\beta 1 \times(\ln (\mathrm{SIZE}))_{i t}+\beta 2 \times(\mathrm{TAX})_{i t}+$ $\beta 3 *(\operatorname{ASSETSTRUCT})_{i t}+\beta 4 \times(\mathrm{PROFIT})_{i t}+\varepsilon_{i t}, \quad$ [Eqn 2] where:

$i$ denotes the cross sections and $t$ denotes the time period with $i=1 \ldots 189$ for the JSE's main board, $i=1 \ldots 45$ for the AltX and $t=1 \ldots 5$. The yearly observations are from 2011 to 2015 .

LEVERAGE $(k)$ represents different leverage measures (total liabilities/net assets, total liabilities/total assets, total liabilities/capital, current liabilities/total assets, non-current liabilities/total liabilities) with $k=1,2,3,4$ and 5 . This equation is run 10 times - once for each measure of leverage for JSE firms and once for each measure of leverage for AltX firms. $\varepsilon_{i t}$ is the normal error term.

$\alpha$ is the constant.

Table 3 presents a summary of the measurement proxies used for the independent or control variables in this study.

Panel data that have distinct advantages over cross-section data were used in this study. This enabled enhanced identification and measurement of effects that are not apparent in pure cross sections or pure time series data. Panel data give more informative data, more variability, less collinearity among the variables, more degrees of freedom and more efficiency (Baltagi 2008; De Jager 2008). Furthermore, panel data are superior to aggregate time series data as the underlying dynamics of the data are not obscured by aggregation bias (Bond 2002).

The study follows precedent by using a 5-year period. SogorbMira (2005) and Lemma and Negash (2011) also used a 5-year period as it reduced the measurement error arising from random year-to-year fluctuations in variables. Additionally, there have been no significant monetary policy changes during the time period that will be covered. This improves the validity of the study.

The classic linear regression model is based on certain assumptions. The model residuals should be normally distributed, there should be homoscedasticity, there should be no autocorrelation between the disturbances and the explanatory variables should not be correlated (Gujarati 2009). Several model diagnostic tests were run to test whether these assumptions were met. When the assumptions were not met, appropriate statistical techniques were employed to ensure that results were reliable.

\section{Results}

In analysing the results of this study, reference is first made to descriptive statistics of the variables.

An analysis of the listing and delisting activities of AltX firms was conducted on the data for the 5-year period of this study. Over the entire period, a total of five firms delisted from and two firms listed on the AltX. None of the five delisted firms went on to list on the JSE's main board.

Further descriptive statistics were calculated after removing the outliers identified in the process detailed in the 'Results' section of this study. Table 4 presents the descriptive statistics for the dependent variables. As with prior research,

TABLE 4: Descriptive statistics of the dependent variable.

\begin{tabular}{lcccccc}
\hline \multirow{2}{*}{ Dependent variable } & \multicolumn{2}{c}{ Mean } & & \multicolumn{2}{c}{ Standard deviation } \\
\cline { 2 - 3 } \cline { 6 - 7 } & JSE & AltX & & JSE & AltX \\
\hline Total liabilities/net assets & 0.683 & 0.735 & & 0.515 & 0.747 \\
Total liabilities/total assets & 0.458 & 0.497 & & 0.191 & 0.294 \\
Total liabilities/total equity & 1.036 & 0.815 & & 2.343 & 4.030 \\
Current liabilities/total assets & 0.297 & 0.354 & & 0.176 & 0.232 \\
Non-current liabilities/total liabilities & 0.351 & 0.267 & & 0.247 & 0.256 \\
\hline
\end{tabular}

AltX, Alternative Exchange; JSE, Johannesburg Securities Exchange. 
it provides evidence that the levels of leverage vary widely depending on how leverage is measured (Bevan \& Danbolt 2002; Gwatidzo \& Ojah 2009; Harris \& Raviv 1991; Lemma \& Negash 2011; Rajan \& Zingales 1995). This is apparent for both indices under analysis. Overall, companies on the AltX have higher levels of total leverage than those on the main board. This may indicate either that the AltX may not be providing the same level of access to equity finance as the JSE or that equity investors prefer shares listed on the main board.

Furthermore, the composition of leverage for JSE and AltX firms is rather different, also suggesting problems with access to capital for AltX firms. Johannesburg Securities Exchange firms make greater use of long-term debt with a higher level of non-current liabilities to total liabilities than AltX firms. Longterm debt may be more difficult to access but presents less liquidity risk than short-term debt for the firm. It appears that firms on the AltX have lower levels of non-current liabilities than firms on the JSE, with the former using current liabilities as a major source of financing. Alternative Exchange firms have significantly higher current liabilities to total assets ratio, consistent with prior findings that firms prefer short-term debt, possibly as it is easier to access (Gwatidzo \& Ojah 2009).

The standard deviations for all measures of leverage are higher for AltX firms, indicating more variations in the capital structures of these firms than JSE firms.

Descriptive statistics of the independent variables (size, profitability, asset structure, tax and listing) are provided in Table 5. Coded variables were used for the measurement of the index listing (CD_Listing). Results from the coded variable may not be interpreted in the same way as the noncoded variables.

As anticipated, the average size of companies listed on the main board of the JSE is larger than companies listed on the AltX. This is supported by maximum values on each index with the JSE's main board having the larger maximum size. Notably, the smallest firm listed on the JSE's main board is smaller than the smallest firm listed on the AltX. We may infer that it is possible that certain companies are listed on the AltX despite possibly qualifying for listing on the JSE's main board. A higher standard deviation for the JSE's main board provides evidence of a more diverse range of companies than those listed on the AltX.

When considering asset structure (measured by the ratio of tangible assets to total assets), the descriptive statistics show similarity between the indices under analysis. Both indices appear to be dominated by firms that have predominantly high levels of tangible assets. However, the minimum values for each index may indicate that more AltX-listed firms have lower levels of tangible assets compared to firms listed on the JSE's main board.

Regarding profitability (measured by the ratio of earnings before interest and tax to total assets), the average profitability of companies listed on the AltX is negative, indicating that, on average, companies on the AltX are loss-making. Their average profitability is also less than firms on the JSE's main board. The greater standard deviation, recorded for AltXlisted companies, provides further evidence of the diverse range of firms on the index.

To test whether the assumptions of a linear regression model, outlined in the 'Research methodology' section, were met, several diagnostic tests were performed. One of the ways in which the assumption of normality is checked is to inspect a normal probability plot (Pallant 2013). For this study, a normal probability plot was generated in $\mathrm{R}$ for each measure of leverage. These plots showed that the residuals approximated a normal distribution. To detect outliers, Cook's distances may be generated (Pallant 2013). Following close examination of the plots, outliers were identified for each of the five different measures of leverage. These were removed from the analysis.

For the panel data analysis in this study, the fixed effects model and the random effects model were estimated. To assess the suitability of each of the models, the Hausman test was conducted for each measure of leverage for Eqn 1 and Eqn 2, respectively. The results of this test indicated that the fixed effects model was preferred in some instances, while the random effects model was preferred in others.

To check for heteroscedasticity, the Breusch-Pagan test was used (Gujarati 2009). While heteroscedasticity was detected, a robust covariance matrix was used to account for it (Croissant \& Millo 2008). The construction of the test statistics using a robust covariance matrix allows more accurate inferences as the matrix allows for heteroscedasticity (Croissant \& Millo 2008; Den Haan \& Levin 1997).

According to Gujarati (2009), the degree of multicollinearity should be measured in a particular sample. Furthermore, there is no single measure of multicollinearity. This study therefore presents the results of several indicators of multicollinearity. A covariance matrix was generated.

TABLE 5: Descriptive statistics of the independent variables in Eqn 2.

\begin{tabular}{|c|c|c|c|c|c|c|c|c|}
\hline \multirow{2}{*}{$\begin{array}{l}\text { Model 2: independent } \\
\text { variables }\end{array}$} & \multicolumn{2}{|c|}{ Mean } & \multicolumn{2}{|c|}{ Standard deviation } & \multicolumn{2}{|c|}{ JSE } & \multicolumn{2}{|c|}{ AltX } \\
\hline & JSE & AltX & JSE & AltX & Max & Min & Max & Min \\
\hline LNSize & 15.236 & 12.135 & 2.063 & 1.449 & 21.598 & 1.609 & 16.349 & 6.428 \\
\hline Profit & 0.070 & -0.108 & 0.369 & 0.662 & 0.693 & -9.923 & 0.443 & -7.806 \\
\hline AssetStruct & 0.887 & 0.803 & 0.143 & 0.258 & 1.000 & 0.053 & 1.000 & 0.008 \\
\hline $\operatorname{Tax}$ & 0.090 & 0.0758 & 3.445 & 0.341 & 17.172 & -88.820 & 2.619 & -1.877 \\
\hline$C D$ Listing & $\mathrm{n} / \mathrm{a}$ & $n / a$ & $\mathrm{n} / \mathrm{a}$ & $n / a$ & 1.000 & 1.000 & -1.000 & -1.000 \\
\hline
\end{tabular}

AltX, Alternative Exchange; JSE, Johannesburg Securities Exchange; n/a, not applicable. 
It showed no evidence of correlation between explanatory variables as all correlations were below the acceptable threshold of 0.7 (Pallant 2013). The largest correlation coefficient is 0.48 , suggesting minimal correlation between explanatory variables.

In the context of several explanatory variables, reliance on simple pairwise correlations as indicators of multicollinearity can be misleading (Gujarati 2009). Therefore, the Pearson correlation coefficient and the variance inflation factor (VIF) were generated. If there is no collinearity, the VIF will be 1 (Gujarati 2009). These indicators of multicollinearity are presented below and provide further evidence that no significant correlation existed between explanatory variables. All Pearson correlation coefficients were less than 0.7 (or more than -0.7) and all VIFs were less than 10 (Gujarati 2009; Pallant 2013).

TABLE 6: Covariance matrix.

\begin{tabular}{lllclc}
\hline Variables & LNSize & Tax & AssetStruct & Profit & CD_Listing \\
\hline LNSize & 1 & - & - & - & - \\
Tax & 0.3085 & 1 & - & - & - \\
AssetStruct & 0.2198 & 0.0442 & 1 & - & - \\
Profit & 0.2137 & 0.2626 & -0.0033 & 1 & - \\
CD_Listing & 0.4772 & 0.3085 & 0.1861 & 0.1402 & 1 \\
\hline
\end{tabular}

TABLE 7: Pearson correlations.

\begin{tabular}{lcccc}
\hline Pearson correlation & Size & Tax & AssetStruct & Profit \\
\hline Size & 1.000 & 0.002 & 0.074 & 0.214 \\
Tax & 0.002 & 1.000 & -0.032 & 0.050 \\
AssetStruct & 0.074 & -0.032 & 1.000 & -0.035 \\
Profit & 0.214 & 0.050 & -0.035 & 1.000 \\
\hline
\end{tabular}

TABLE 8: Variance inflation factors.

\begin{tabular}{lcc}
\hline Variables & \multicolumn{2}{c}{ Collinearity statistics } \\
\cline { 2 - 3 } & Tolerance & Variance inflation factor \\
\hline Size & 0.948 & 1.055 \\
Tax & 0.997 & 1.003 \\
AssetStruct & 0.991 & 1.009 \\
Profit & 0.949 & 1.053 \\
\hline
\end{tabular}

Note: The results from the regression equations are presented and discussed overleaf.

\section{Listing}

The results show that even when controlling for the other possible determinants of capital structure, firms listed on the AltX have higher levels of debt than firms listed on the JSE's main board. This substantiates the findings in the 'Descriptive statistics' section of this study. The listing is significant at the $0.1 \%$ level when measuring leverage as non-current liabilities scaled by total debt and at the $5 \%$ level when measuring leverage as current liabilities scaled by total assets. Considering the coding of the index variable (AltX (-1), JSE (1)), the negative coefficient indicates that companies on the AltX, on average, have higher levels of leverage than those listed on the JSE's main board, when controlling for other possible influences on capital structure.

The higher levels of leverage for AltX firms may be as a result of them not enjoying the same access to capital as those listed on the JSE. According to Olawale and Garwe (2010), one of the main obstacles inhibiting SME growth is poor credit rating. These poor credit ratings may be as a result of lower profitability and the accumulation of too much debt (especially current liabilities). This would substantiate the findings of higher levels of leverage as well as a negative mean profitability detected in AltX firms in the 'Descriptive statistics' section of this study.

Firms with higher leverage ratios are more likely to default on their debt (Correia 2015). If these findings do indeed point to most AltX firms being in financial distress, they may have to rely more on equity financing so as to reduce the agency costs of debt. However, financially distressed firms may incur high costs of equity. This situation will result in firms facing considerable difficulty in raising both equity and debt finance (Moyo et al. 2013).

The significant result obtained when measuring leverage with reference to current liabilities may indicate that firms listed on the AltX are more likely than firms listed on the JSE to use more short-term debt as a financing option. This

TABLE 9: Regression results: Eqn 1.

\begin{tabular}{|c|c|c|c|c|c|}
\hline Leverage & Total liabilities/net assets & Total liabilities/total assets & Total debt/total equity & Current liabilities/total assets & Non-current liabilities/total debt \\
\hline Model chosen & Fixed effects & Fixed effects & Fixed effects & Fixed effects & Fixed effects \\
\hline \multirow[t]{2}{*}{ Intercept } & 0.465 & 0.041 & -6.096 & 0.149 & 0.301 \\
\hline & $(0.269)$ & $(0.087)$ & $(2.219)$ & $(0.072)$ & $(0.082)$ \\
\hline \multirow[t]{2}{*}{ LNSize } & 0.008 & 0.025 & 0.588 & 0.012 & 0.020 \\
\hline & $(0.012)$ & $(0.004)^{* * *}$ & $(0.118)^{* * *}$ & $(0.003)^{* * *}$ & $(0.005)^{* * *}$ \\
\hline \multirow[t]{2}{*}{$\operatorname{Tax}$} & 0.003 & 0.0003 & -0.002 & -0.0007 & 0.0005 \\
\hline & $(0.004)$ & $(0.001)$ & $(0.028)$ & $(0.001)$ & $(0.002)$ \\
\hline \multirow[t]{2}{*}{ AssetStruct } & 0.351 & 0.114 & -1.014 & 0.146 & -0.299 \\
\hline & $(0.156)^{*}$ & $(0.051)^{*}$ & $(1.281)$ & $(0.043)^{* * *}$ & $(0.057)^{* * *}$ \\
\hline \multirow[t]{2}{*}{ Profit } & -0.1957 & -0.111 & 0.822 & -0.125 & 0.027 \\
\hline & $(0.082) * * *$ & $(0.027)^{* * *}$ & $(0.587)$ & $(0.033) * * *$ & $(0.033)$ \\
\hline \multirow[t]{2}{*}{ CD_Listing } & -0.206 & -0.045 & -1.022 & -0.188 & 0.027 \\
\hline & $(0.251)$ & $(0.082)$ & (1.784) & $(0.074)^{*}$ & $(0.017)^{* * *}$ \\
\hline Hausman test ( $p$-value) & 0.0001937 & 0.04282 & 0.006189 & 0.03933 & 0.0039 \\
\hline Probability ( $F$-stat) & 0.0000 & 0.0000 & 0.0000 & 0.0000 & 0.0000 \\
\hline
\end{tabular}

Notes: Robust standard error values are given in parentheses.

$*$, indicates significance at $5 \% ; * *$, indicates significance at $1 \% ; * *$, indicates significance at $0.1 \%$. Variables that do not contain asterisks $(*)$ were not significant, even at the $10 \%$ level. 
finding is consistent with prior literature which found that smaller firms rely more on short-term debt (Bevan \& Danbolt 2002; Bhaduri 2002; Gwatidzo \& Ojah 2009; Titman \& Wessels 1988) and validates the postulation by Cook and Nixson (2000) that SMEs do not have access to appropriate forms of credit (emphasis added). This lack of access to relatively less risky forms of finance may result in an increased cost of capital as a result of financial distress, compounding the difficulties that Alt $X$ firms face in accessing long-term capital.

Having established that there is a difference in capital structure between the JSE- and AltX-listed firms, the rest of this section aims to analyse the difference in more detail. To this end, results from Eqn 2 are presented and discussed.

\section{Size}

Consistent with prior literature, in JSE-listed firms, size is found to be a significant and positive determinant of leverage (Booth et al. 2001; Chipeta et al. 2012; Gwatidzo, Ntuli \& Mlilo 2016; Rajan \& Zingales 1995) irrespective of how leverage is measured. Size was found to be significant at the $0.1 \%$ level for four of the five measures of leverage for JSE-listed firms. This means that the greater the size, the greater the leverage on average for JSE-listed firms. Notably, size is not shown to be significant for AltX-listed firms. It appears that size has a greater significance for a firm listed on the JSE. This may be because of external providers of finance viewing all AltX-listed firms as 'small', a view that may be supported by the lower standard deviation of the size variable for AltX firms compared to JSE firms in the 'Descriptive statistics' section.

\section{Taxation}

Taxation was not found to be a significant determinant of capital structure for JSE- and AltX-listed firms for two of the five measures of leverage. This is consistent with the findings of Gwatidzo and Ojah (2009) where the tax variable was insignificant for South African firms. As outlined in the 'Literature review' section, findings on the relationship between debt and taxes are varied. The findings of this study are largely consistent with those of Negash (2002) where a negative association between leverage and the tax variable was discovered.

TABLE 10: Regression results: Eqn 2 - Johannesburg Securities Exchange-listed firms.

\begin{tabular}{|c|c|c|c|c|c|}
\hline Leverage & Total liabilities/Net assets & Total liabilities/Total assets & Total debt/Total equity & Current liabilities/Total assets & Non-current liabilities/Total debt \\
\hline Model chosen & Fixed effects & Fixed effects & Fixed effects & Fixed effects & Fixed effects \\
\hline \multirow[t]{2}{*}{ Intercept } & 0.233 & -0.0005 & -5.754 & 0.033 & 0.156 \\
\hline & $(0.158)$ & $(0.068)$ & $(1.527)$ & $(0.052)$ & $(0.085)$ \\
\hline \multirow[t]{2}{*}{ LNSize } & 0.015 & 0.029 & 0.440 & 0.012 & 0.023 \\
\hline & $(0.008) \dagger$ & $(0.003)^{* * *}$ & $(0.080)^{* * *}$ & $(0.002) * * *$ & $(0.004)^{* * *}$ \\
\hline Tax & 0.002 & -0.0002 & -0.002 & -0.0009 & 0.0007 \\
\hline \multirow[t]{2}{*}{ AssetStruct } & 0.282 & 0.036 & 0.084 & 0.110 & -0.186 \\
\hline & $(0.121)^{*}$ & $(0.052)$ & $(1.017)$ & $(0.044)^{*}$ & $(0.065)^{* *}$ \\
\hline \multirow[t]{2}{*}{ Profit } & -0.267 & -0.062 & 0.549 & -0.191 & 0.078 \\
\hline & $(0.061)^{* * *}$ & $(0.026)^{*}$ & $(0.572)$ & $(0.036) * * *$ & $(0.034)^{*}$ \\
\hline Hausman test ( $p$-value) & 0.00008958 & 0.003128 & 0.00566 & 0.00017 & 0.0001765 \\
\hline Probability ( $F$-stat) & 0.0000 & 0.0000 & 0.0000 & 0.0000 & 0.0000 \\
\hline
\end{tabular}

Notes: Robust standard error values are given in parentheses.

$*$, indicates significance at $5 \%$; **, indicates significance at $1 \%$; **, indicates significance at $0.1 \%$. Variables that do not contain asterisks $(*)$ were not significant, even at the $10 \%$ level.

TABLE 11: Regression results: Eqn 2 - Alternative-Exchange-listed firms.

\begin{tabular}{|c|c|c|c|c|c|}
\hline Leverage & Total liabilities/net assets & Total liabilities/total assets & Total debt/total equity & Current liabilities/total assets & Non-current liabilities/total debt \\
\hline Model chosen & Random effects & Random effects & Random effects & Random effects & Random effects \\
\hline \multirow[t]{2}{*}{ Intercept } & -0.088 & -0.094 & 1.749 & -0.122 & 0.849 \\
\hline & $(0.556)$ & $(0.205)$ & $(3.066)$ & $(0.170)$ & $(0.181)^{* * *}$ \\
\hline \multirow[t]{2}{*}{ LNSize } & 0.020 & 0.031 & -0.091 & 0.021 & -0.022 \\
\hline & $(0.052)$ & $(0.019)$ & $(0.287)$ & $(0.015)$ & $(0.016)$ \\
\hline \multirow[t]{2}{*}{ Tax } & 0.025 & -0.005 & -0.016 & 0.007 & -0.048 \\
\hline & $(0.122)$ & $(0.038)$ & $(0.964)$ & $(0.034)$ & $(0.032)$ \\
\hline \multirow[t]{2}{*}{ AssetStruct } & 0.802 & 0.311 & 0.249 & 0.311 & -0.363 \\
\hline & $(0.337)^{*}$ & $(0.122)^{*}$ & $(1.834)$ & $(0.102)^{* *}$ & $(0.097)^{* * *}$ \\
\hline \multirow[t]{2}{*}{ Profit } & -1.207 & -0.365 & 0.663 & -0.095 & -0.164 \\
\hline & $(0.224)^{* * *}$ & $(0.072)^{* * *}$ & (1.668) & $(0.064)$ & $(0.062)^{* *}$ \\
\hline Hausman test ( $p$-value) & 0.487 & 0.08336 & 0.8779 & 0.149 & 0.4458 \\
\hline Probability ( $F$-stat) & 0.0000 & 0.0000 & 0.9855 & 0.0000 & 0.0000 \\
\hline
\end{tabular}

Notes: Robust standard error values are given in parentheses.

$*$, indicates significance at $5 \% ; * *$, indicates significance at $1 \% ; * *$, indicates significance at $0.1 \%$. Variables that do not contain asterisks $(*)$ were not significant, even at the $10 \%$ level. 


\section{Asset structure}

For firms across both bourses, asset structure is found to be significant for three out of the five measures of leverage. The positive coefficients show that the higher the tangible assets relative to total asset base, the higher the leverage. This may suggest that firms use their asset bases as collateral for debt, thereby reducing transaction costs associated with information asymmetry. Overall, the quantum of the coefficients for asset structure is much larger for AltX firms. This indicates that having tangible assets is more important for AltX firms as they have a greater need than JSE firms to provide collateral to providers of debt, possibly as a result of increased information asymmetry.

\section{Profitability}

Consistent with prior literature (Gwatidzo \& Ojah 2009; Lemma \& Negash 2011), profitability is found to be a significant determinant of capital structure for JSE-listed firms. Assuming profitability proxies for availability of internal resources, the predominantly negative coefficients suggest that the higher the profitability of the firm, the lower the leverage, possibly supporting theories on pecking order. Firms listed on JSE appear to be using internal resources for financing, if these are available.

Interestingly, profitability is also found to be a significant determinant of capital structure in AltX firms. In fact, it is the only measure that was found to be significant at the $0.1 \%$ level for two measures of leverage for the AltX. It appears to have the strongest explanatory power of the variation in leverage of AltX-listed firms. The negative coefficients provide strong support for AltX firms following the pecking order, possibly because of high transaction costs associated with debt or the inability to access it.

Although profitably is significant for both indices, the finding is of particular relevance to AltX firms. The descriptive statistics showed a negative mean profitability for AltX firms, suggesting that, on average, these firms are not profitable. If AltX firms are likely to draw on their profits as their first source of finance and if profits are unavailable, this may pose a severe constraint to their growth and survival. These inferences validate findings from prior research into South African SMEs, in which difficulty in obtaining finance is regarded as a serious problem facing small businesses (Cant \& Ligthelm 2002; Olawale \& Garwe 2010).

\section{Conclusion and recommendation for future research \\ Access to finance for Alternative Exchange companies}

The objective of this study was to investigate whether the AltX has enabled equivalent access to finance for SMEs as the JSE's main board has performed for larger firms. To achieve this, an analysis of the capital structures of firms on both indices was performed. The results indicate that after controlling for the major factors that have previously been found to influence capital structure, a dissimilarity between AltX and JSE firms' capital structures does exist. Although AltX firms on average have more total debt, this debt is more likely to be current liabilities, consistent with Gwatidzo and Ojah (2009). This suggests that the AltX may be only partially addressing the challenges that SMEs face when attempting to access finance.

\section{Support for the pecking order theory}

Largely consistent with prior work (Gwatidzo \& Ojah 2009; Lemma \& Negash 2011), the study found support for the pecking order theory in both JSE- and AltX-listed firms. Notably, AltX firms on average, although not profitable, prefer to use internal sources of finance rather than debt. When these firms do require finance, they appear to resort to short-term debt, resulting in greater liquidity risk as current liabilities may be used to finance non-current assets, resulting in a timing mismatch between cash inflows and cash outflows. This makes them more susceptible to financial distress, increasing their cost of capital, making it yet more difficult to access much-needed long-term finance.

\section{Recommendations for further research}

The findings in this study may form a good basis for further research into SMEs - both listed and unlisted. To further assess the effectiveness of the AltX in providing access to finance to SMEs, a comparison of listed to unlisted SMEs is required. Although financial data on unlisted SMEs may not be readily available, qualitative research methods may be used to complement empirical research. While the findings in this study are a result of a carefully constructed analytical process, the inferences based on the findings are based on the authors' interpretations as well as prior literature. Further, valuable insights are possible from conducting interviews with owners and managers of AltX-listed firms.

This study's findings that taxation is not a significant factor in determining capital structure highlights that this is an area for further research. Several variables have been employed in prior studies as measurement proxies. Sebastian and Kransdorff (2017) use a coded tax variable. Further alternative measures of taxation may shed light on the finding that there appears to be a contradiction between the theoretical framework and empirical results.

Furthermore, the scope of the study could be extended to other developing economies with the objective of including country-specific factors that may influence capital structure decisions. These country-specific factors may include bankruptcy laws, monetary policy and competition in the financial sector.

\section{Acknowledgements}

The authors would like to thank Michael Kransdorff for his input on the formulation of the methodology. This article 
is based on a paper presented at the 2017 Southern African Accounting Association International Conference, titled: 'Does the index matter? A comparison of the capital structures of firms listed on the AltX to those listed on the JSE' by Avani Sebastian and Michael Kransdorff, available at: http:/ / tiny. cc/MAF012

\section{Competing interests}

The authors declare that they have no financial or personal relationships that may have inappropriately influenced them in writing this article.

\section{Authors' contributions}

A.S. wrote the article and performed the statistical modelling and also incorporated review comments and feedback from the second author. A.M. provided review comments and suggestions for improvement on the content and structure of the manuscript.

\section{Ethical considerations}

The research is based on published data that is available from research databases and does not include data obtained via surveys and/or interviews. The research project upon which this article is based was evaluated by an established research committee at the University (in the School of Accountancy) and no further ethical clearances were deemed necessary by the committee.

\section{Funding}

This research received no specific grant from any funding agency in the public, commercial or not-for-profit sectors.

\section{Data availability statement}

Data sharing is not applicable to this article as no new data were created or analysed in this study.

\section{Disclaimer}

The views expressed in this article are those of the authors and not the official position of the University of the Witwatersrand.

\section{References}

Abor, J. \& Quartey, P., 2010, 'Issues in SME development in Ghana and South Africa', International Research Journal of Finance and Economics 39(6), 215-228.

Akerlof, G.A., 1970, 'The market for "lemons": Quality uncertainty and the market mechanism', The Quarterly Journal of Economics 84(3), 488-500. https://doi. org/10.2307/1879431

Ang, J.S., 1992, 'On the theory of finance for privately held firms', The Journal of Entrepreneurial Finance 1(3), 185 - 203.

Ang, J.S., Chua, J.H. \& McConnell, J.J., 1982, 'The administrative costs of corporate bankruptcy: A note', The Journal of Finance 37(1), 219-226. https://doi. org/10.1111/j.1540-6261.1982.tb01104.x

Arestis, P., Demetriades, P.O. \& Luintel, K.B., 2001, 'Financial development and economic growth: The role of stock markets', Journal of Money, Credit and Banking 107(442), 16-41. https://doi.org/10.2307/2673870

Baltagi, B., 2008, Econometric analysis of panel data, John Wiley \& Sons, New York.
Banerjee, A.A., 2006, 'Capital market access to SMES in India', paper presented the 10th Indian Institute of Capital Markets conference paper, Indian Institute of Capital Markets, New Delhi, 18th December.

Beneke, J., 2016, 'Benchmarking value creation of companies listed on the JSE's AltX', International Journal of Economics and Finance Studies 8(1), 131-144.

Bevan, A.A. \& Danbolt, J., 2002, 'Capital structure and its determinants in the UK-a decompositional analysis', Applied Financial Economics 12(3), 159-170. https:// doi.org/10.1080/09603100110090073

Bevan, A.A. \& Danbolt, J., 2004, 'Testing for inconsistencies in the estimation of UK capital structure determinants', Applied Financial Economics 14(1), 55-66. https://doi.org/10.1007/s10258-002-0009-9

Bhaduri, S.N., 2002, 'Determinants of capital structure choice: A study of the Indian corporate sector', Applied Financial Economics 12(9), 655-665. https://doi. org/10.1080/09603100010017705

Bond, S.R., 2002, 'Dynamic panel data models: A guide to micro data methods and practice', Portuguese Economic Journal 1(2), 141-162. https://doi.org/10.1007/ s10258-002-0009-9

Booth, L., Aivazian, V., Demirguc-Kunt, A. \& Maksimovic, V., 2001, 'Capital structures in developing countries', The Journal of Finance 56(1), 87-130. https://doi.org/ 10.1111/0022-1082.00320

Bowman, R.G., 1980, 'The importance of a market-value measurement of debt in assessing leverage', Journal of Accounting Research 18(1), 242-254. https://doi. org/10.2307/2490400

Brown, S.J., Goetzmann, W., Ibbotson, R.G. \& Ross, S.A., 1992, 'Survivorship bias in performance studies', Review of Financial Studies 5(4), 553-580. https://doi. org $/ 10.1093 / \mathrm{rfs} / 5.4 .553$

Cant, M.C. \& Ligthelm, A., 2002, 'Small business problems in the South African context: A proactive entrepreneurial approach', paper presented at the Paper delivered at the 7th Asia-Pacific Decision Sciences Institute conference, University of South Africa, Bureau of Market Research, Pretoria, July.

Chipeta, C., Wolmarans, H. \& Vermaak, F., 2012, 'Impact of financial liberalisation on capital structure: Evidence from the Johannesburg Securities Exchange', African Journal of Business Management 6(5), 1984.

Chipeta, C., Wolmarans, H.P., Vermaak, F.N. \& Proudfoot, S., 2013, 'Structural breaks in the parameter estimates of the determinants of capital structure: Some evidence from the JSE', Meditari Accountancy Research 21(1), 68-84. https://doi. org/10.1108/MEDAR-07-2012-0025

Cook, P. \& Nixson, F., 2000, Finance and small and medium-sized enterprise development, Institute for Development Policy and Management, Manchester.

Correia, C., 2015, Financial management, Juta, Cape Town.

Correia, C. \& Cramer, P., 2008, 'An analysis of cost of capital, capital structure and capital budgeting practices: A survey of South African listed companies', Meditar Accountancy Research 16(2), 31-52. https://doi.org/10.1108/10222529200800011

Correia, C. \& Holman, G., 2008, 'An analysis of underpricing and aftermarket performance of initial public offerings on the Alternative Exchange (AltX)', South African Journal of Accounting Research 22(1), 97-117. https://doi.org/10.1080/ 10291954.2008.11435133

Croissant, Y. \& Millo, G., 2008, 'Panel data econometrics in R: The plm package', Journal of Statistical Software 27(2), 1-43. https://doi.org/10.18637/jss.v027.i02

Damodaran, A., 2010, Applied corporate finance, John Wiley \& Sons, New York.

De Jager, P., 2008, 'Panel data techniques and accounting research', Meditari Accountancy Research 16(2), 53-68. https://doi.org/10.1108/10222529200800012

De Wet, L.H. \& Gossel, S.J., 2016, 'South African capital structure decisions: A survey of listed companies', Journal of African Business 17(2), 167-187. https://doi.org/ 10.1080/15228916.2016.1132509

Den Haan, W.J. \& Levin, A.T., 1997, '12: A practitioner's guide to robust covariance matrix estimation', Handbook of Statistics 15, 299-342. https://doi.org/10.1016/ S0169-7161(97)15014-3

Falkena, H., Abedian, I., Von Blottnitz, M., Coovadia, C., Davel, G., Madungandaba, J. et al., 2007, SMEs' access to finance in South Africa: A supply-side regulatory review, Pretoria, National Treasury.

Gerakos, J., Lang, M. \& Maffett, M., 2013, 'Post-listing performance and private sector regulation: The experience of London's alternative investment market', Journa of Accounting and Economics 56(2), 189-215. https://doi.org/10.1016/j.jacceco. 2013.08.004

Gordhan, P., 2017, Budget speech, Pretoria, viewed 16 March 2019, from http://www. gov.za/SPEECHES/MINISTER-PRAVIN-GORDHAN-2017-BUDGET-SPEECH-22-FEB2017-0000.

Graham, J.R., 2000, 'How big are the tax benefits of debt?', The Journal of Finance 55(5), 1901-1941. https://doi.org/10.1111/0022-1082.00277

Gujarati, D.N., 2009, Basic econometrics, Tata McGraw-Hill Education, New York.

Gwatidzo, T., Ntuli, M. \& Mlilo, M., 2016, 'Capital structure determinants in South Africa: A quantile regression approach',. Journal of Economic and Financial Sciences 9(1), 275-290.

Gwatidzo, T. \& Ojah, K., 2009, 'Corporate capital structure determinants: Evidence for five African countries', African Finance Journal 11(1), 1-23. https://doi.org/ 10.4102/jef.v9i1.42

Harris, M. \& Raviv, A., 1991, 'The theory of capital structure', The Journal of Finance 46(1), 297-355. https://doi.org/10.1111/j.1540-6261.1991.tb03753.x

Holman, G., Van Breda, R. \& Correia, C., 2011, 'The use of the Merton model to quantify the default probabilities of the top 42 non-financial South African firms', The African Finance Journal 13(Conference Issue), 1-33. 
Holmes, S. \& Kent, P., 1991, 'An empirical analysis of the financial structure of smal and large Australian manufacturing enterprises', The Journal of Entrepreneurial Finance 1(2), 141.

Jensen, M.C., 1986, 'Agency cost of free cash flow, corporate finance, and takeovers', Corporate Finance, and Takeovers. American Economic Review 76(2), 323-329.

JSE, 2013, AltX, viewed 16 March 2019, from https://www.jse.co.za/capital/altx.

JSE, 2016, Guidelines to listing on the JSE, Lexis Nexis Butterworths Publishers, viewed 16 March 2019, from https://www.jse.co.za/content/JSESpecificationsltems/ Guidelines $\% 20$ to $\% 20$ Listing $\% 20$ on $\% 20$ the $\% 20 J S E$.pdf.

Kraus, A. \& Litzenberger, R.H., 1973, 'A state-preference model of optimal financial leverage', The Journal of Finance 28(4), 911-922. https://doi.org/10.1111/j.15406261.1973.tb01415.x

Lee, W.Y. \& Barker, H.H., 1977, 'Bankruptcy costs and the firm's optimal debt capacity: A positive theory of capital structure', Southern Economic Journal 43(4), 1453-1465. https://doi.org/10.2307/1057111

Leedy, P. \& Ormrod, J.E., 2012, Practical research planning and design, Pearson, London.

Lemma, T.T. \& Negash, M., 2011, 'Rethinking the antecedents of capital structure of Johannesburg Securities Exchange listed firms', Afro-Asian Journal of Finance and Accounting 2(4), 299-332. https://doi.org/10.1504/AAJFA.2011.043867

Letsoenya, S. \& Negash, M., 2013, 'Equity ownership patterns and corporate financing choices of listed South African firms', paper presented at the Southern African Accounting Association, Cape Town, June 2013, Southern African Accounting Association, Johannesburg, June.

Long, M.S. \& Malitz, I.B., 1985, 'Investment patterns and financial leverage', in Corporate capital structures in the United States, pp. 325-352, University of Chicago Press, Chicago, IL.

Mendoza, J.M., 2008, 'Securities regulation in low-tier listing venues: The rise of the alternative investment market', Fordham Journal of Corporate \& Financial Law 13, 257.

Miller, M.H., 1977, 'Debt and taxes', The Journal of Finance 32(2), 261-275. https:// doi.org/10.1111/j.1540-6261.1977.tb03267.x

Modigliani, F. \& Miller, M.H., 1958, 'The cost of capital, corporation finance and the theory of investment', The American Economic Review 48(3), 261-297.

Modigliani, F. \& Miller, M.H., 1963, 'Corporate income taxes and the cost of capital: A correction', The American Economic Review 53(3), 433-443.

Moyo, V., Wolmarans, H. \& Brummer, L., 2013, 'Dynamic capital structure determinants: Some evidence from South African firms', Journal of Economic and Financial Sciences 6(3), 661-682.

Myers, S.C. \& Majluf, N.S., 1984, 'Corporate financing and investment decisions when firms have information that investors do not have', Journal of Financial Economics 13(2), 187-221. https://doi.org/10.1016/0304-405X(84)90023-0
Negash, M., 2002, 'Corporate tax and capital structure: Some evidence and implications', Investment Analysts Journal 31(56), 17-27. https://doi.org/10.1080/ 10293523.2002.11082439

Olawale, F. \& Garwe, D., 2010, 'Obstacles to the growth of new SMEs in South Africa: A principal component analysis approach', African Journal of Business Management 4(5), 729.

Pallant, J., 2013, SPSS survival manual, McGraw-Hill Education, London, UK.

Perera, H., 2015, 'The effects of macroeconomic conditions on corporate capital structure: Evidence from manufacturing firms listed in Colombo Stock Exchange', International Journal of Science and Research 4(10), 1492-1497.

Prasad, S., Green, C.J. \& Murinde, V., 2001, Corporate financial structures in developing economies: Evidence from a comparative analysis of Thai and Malay corporations, Institute for Development Policy and Management, Manchester.

Rajan, R.G. \& Zingales, L., 1995, 'What do we know about capital structure? Some evidence from international data', The Journal of Finance 50(5), 1421-1460. https://doi.org/10.1111/j.1540-6261.1995.tb05184.x

Ramjee, A. \& Gwatidzo, T., 2012, 'Dynamics in capital structure determinants in South Africa', Meditari Accountancy Research 20(1), 52-67. https://doi.org/10.1108/ 10222521211234228

Sardo, F. \& Serrasqueiro, Z., 2017, 'Does dynamic trade-off theory explain Portuguese SME capital structure decisions?', Journal of Small Business and Enterprise Development 24(3), 485-502. https://doi.org/10.1108/JSBED-12-2016-0193

Scholtz, H. \& Smit, A.-R., 2015, 'Factors influencing corporate governance disclosure of companies listed on the Alternative Exchange (AltX) in South Africa', South African Journal of Accounting Research 29(1), 29-50. https://doi.org/10.1080/10291954. 2015.999471

Sebastian, A. \& Kransdorff, M., 2017, 'MAF012 does the index matter? A comparison of the capital structures of firms listed on the AltX to those listed on the JSE', Biennial International Conference Proceedings of the Southern African Accounting Association, Drakensberg, June 2017, Southern African Accounting Association, Johannesburg, June.

SEDA, 2016, The small, medium and micro enterprise sector of South Africa, Bureau for Economic Research, Cape Town.

Sogorb-Mira, F., 2005, 'How SME uniqueness affects capital structure: Evidence from a 1994-1998 Spanish data panel', Small Business Economics 25(5), 447-457. https://doi.org/10.1007/s11187-004-6486-8

Titman, S. \& Wessels, R., 1988, 'The determinants of capital structure choice', The Journal of Finance 43(1), 1-19. https://doi.org/10.1111/j.1540-6261.1988. tb02585.x

Van Heerden, C., 2015, 'Is the AltX doing what it is supposed to do? An analysis of the JSE alternative exchange', Masters in Business Administration, Stellenbosch University.

Yartey, C.A. \& Adjasi, C.K., 2007, Stock market development in sub-Saharan Africa: Critical issues and challenges, 7(209), International Monetary Fund. 